medRxiv preprint doi: https://doi.org/10.1101/2020.06.02.20113423; this version posted June 2, 2020. The copyright holder for this preprint

(which was not certified by peer review) is the author/funder, who has granted medRxiv a license to display the preprint in perpetuity.

All rights reserved. No reuse allowed without permission.

\title{
Predictors to use mobile apps for monitoring COVID-19 symptoms and contact tracing: A survey among Dutch citizens.
}

\author{
Stephanie Jansen - Kosterink ${ }^{1,2}$, Marian Hurmuz ${ }^{1,2}$,Marjolein den Ouden ${ }^{3,4}$ and Lex van Velsen ${ }^{1,2}$
}

\author{
${ }^{1}$ Roessingh Research and Development, eHealth group, Enschede, the Netherlands \\ ${ }^{2}$ University of Twente, Faculty of Electrical Engineering, Mathematics and Computer Science, Telemedicine group, \\ Enschede, the Netherlands \\ ${ }^{3}$ Saxion University of Applied Sciences, Research Center of Technology, Health \& Care, Enschede, The Netherlands \\ ${ }^{4}$ ROC van Twente, Research Center Care and Technology, Hengelo, The Netherlands
}

Keywords: COVID-19, eHealth, mHealth, contact tracing, symptom management, intention to use

Abstract: Introduction: eHealth applications have been recognized as a valuable tool to reduce COVID-19's effective reproduction number. In this paper, we report on an online survey among Dutch citizens with the goal to identify antecedents of acceptance of a mobile application for COVID-19 symptom recognition and monitoring, and a mobile application for contact tracing.

Methods: Next to the demographics, the online survey contained questions focussing on perceived health, fear of COVID-19 and intention to use. We used snowball sampling via posts on social media and personal connections. To identify antecedents of acceptance of the two mobile applications we conducted multiple linear regression analyses.

Results: In total, 238 Dutch adults completed the survey. Almost $60 \%$ of the responders were female and the average age was 45.6 years (SD \pm 17.4$)$. For the symptom app, the final model included the predictors age, attitude towards technology and fear of COVID-19. The model had an $R^{2}$ of 0.141. The final model for the tracing app included the same predictors and had an $R^{2}$ of 0.156 . The main reason to use both mobile applications was to control the spread of the COVID-19 virus. Concerns about privacy was mentioned as the main reason not to use the mobile applications.

Discussion: Age, attitude towards technology and fear of COVID-19 are important predictors of the acceptance of COVID-19 mobile applications for symptom recognition and monitoring and for contact tracing. These predictors should be taken into account during the development and implementation of these mobile applications to secure acceptance. 
medRxiv preprint doi: https://doi.org/10.1101/2020.06.02.20113423; this version posted June 2, 2020. The copyright holder for this preprint (which was not certified by peer review) is the author/funder, who has granted medRxiv a license to display the preprint in perpetuity.

All rights reserved. No reuse allowed without permission.

\section{Introduction}

It is spring 2020 and the COVID-19 pandemic has the world in its grip. Infection with COVID-19 can lead to a simple cold or no symptoms at all, while it can also rapidly develop into a life threatening disease, especially for patients with existing cardiovascular problems, obesity, or diabetes [1]. Death by COVID-19 is most often the result of massive alveolar damage and progressive respiratory failure [2]. Treatment of a severe COVID-19 infection can involve admission to the Intensive Care (IC) unit of a hospital, where the patient may be kept in a state of sleep and may be supported via artificial respiration. A stay at the IC may take weeks, resulting in high pressure on the availability of IC beds. In order to hamper the spread of COVID-19 and to manage the IC capacity, many countries have applied a lockdown strategy for their citizens [3]. At the moment of writing this article (May 2020), the spread of the virus is declining in Europe, and countries are loosening the restrictions, like lockdown they imposed upon their citizens. In order to control the spread of COVID-19 after a lockdown, and to minimize the effective reproduction number of the disease, several measures can be applied, of which social distancing, combined with aggressive case-finding and isolation seem to be the most effective [4].

eHealth applications have been recognized as a valuable tool for supporting symptom recognition and monitoring [5], for contact tracing [6], and ultimately, for reducing COVID-19's effective reproduction number by means of timely intervention. In short, a contact tracing app would record a citizen's contacts with other people via Bluetooth technology and, in the case of a COVID-19 infection, will warn the persons that the index patient recently had contact with so that they can apply self-isolation and be attentive for any COVID-19 symptoms. However, for such applications to be effective, high uptake among the population is necessary. For the case of a tracing application, it has been estimated that $56 \%$ of a country's population should use the application to suppress the epidemic [7]. It is therefore crucial that the design of these applications and the implementation strategies that accompany them take the factors that affect acceptance into account.

The factors that determine acceptance of COVID-19 apps are largely unknown [8]. The exception here is privacy. Since the first plans of governments to implement these technologies, a fierce public debate has erupted on whether or not large scaling tracing of contacts for this goal is an unacceptable breach of privacy or not. While the issue of privacy has been recognized as an important antecedent of acceptance of mobile health applications [9], the unique and disturbing situation that the COVID-19 pandemic places us in, makes it difficult to apply existing models and frameworks for eHealth acceptance. The Dutch government wants to develop and implement two mobile applications to prevent the spread of the COVID-19 virus and support Dutch municipal health services. In this paper, we report on an online survey among Dutch citizens with the goal to identify antecedents of acceptance of 1 ) a mobile application for COVID-19 symptom recognition and monitoring, and 2) a mobile application for contact tracing.

\section{Methods}

To identify antecedents of acceptance of a mobile application for COVID-19 symptoms recognition and monitoring (hereafter: symptom app), and a mobile application for contact tracing (hereafter: tracing app), an online survey was developed, tested and distributed among Dutch citizens. This study did not require formal ethical approval (as ruled by CMO Arnhem Nijmegen, file number: 2020-6628). At the beginning of the survey, participants were asked for consent to use their data for research purposes. 
medRxiv preprint doi: https://doi.org/10.1101/2020.06.02.20113423; this version posted June 2, 2020. The copyright holder for this preprint (which was not certified by peer review) is the author/funder, who has granted medRxiv a license to display the preprint in perpetuity.

All rights reserved. No reuse allowed without permission.

\subsection{Survey}

The online survey (see appendix 1) consisted of four parts. The first part included questions on demographics, the second part contained questions related to perceived health, the third part consisted of questions related to the fear of a COVID-19 infection, and the final part included questions to assess the intention to use the two suggested mobile applications. In April 2020, the Dutch government announced plans to develop and implement two mobile applications for preventing the spread of the COVID-19 virus. However, the exact design of these applications remained unknown at this time. Therefore, we introduced both mobile applications in the survey via a short description of their general aim. We pre-tested the survey with 14 Dutch citizens to improve legibility.

\subsubsection{Demographics}

We assessed gender, age, smartphone use, educational level (student, primary school, secondary school, high school, bachelor's degree / University / PhD), work status (unemployed and searching for work, not able to work due to illness, volunteer work, part-time work, full-time work, retired, student), income level (below average wages, average wages, above average wages) and living status (living alone, living together, other). We assessed the participants' attitude towards technology, using the Personal Innovativeness in the Domain of Information Technology scale by Agarwal \& Prasad, 1998 [10], consisting of four statements and accompanied by a five-point Likert scale (ranging from 1 (strongly disagree) to 5 (strongly agree)). Finally, we also asked whether participants were (once) infected with COVID-19. The answer options for this question were: Yes, In doubt, or No.

\subsubsection{Perceived health}

To assess perceived health, we asked participants to complete three questions. These questions were used previously to assess perceived health among Dutch citizens [11]. These questions/statements were: 1 . How would you describe your health?; 2 . How concerned are you about your health?; and 3. I am ill more often than other people of the same age and sex. These were accompanied by a five-point Likert scale ranging from 1 (bad, not concerned and totally disagree, respectively) to 5 (excellent, very concerned and totally agree, respectively).

\subsubsection{Fear of COVID-19}

The participants' fear of a COVID-19 infection was assessed by means of four questions related to this topic.

- Have you been concerned about the outbreak of the COVID-19 virus in recent weeks? [five-point Likert scale, ranging from 1 (not at all concerned) to 5 (extremely concerned)];

- How often did you think of the outbreak of the COVID-19 virus in recent weeks? [five-point Likert scale, ranging from 1 (never) to 5 (always)];

- How afraid were you of the outbreak of the COVID-19 virus in recent weeks? [five-point Likert scale, ranging from 1 (not afraid at all) to 5 (very afraid)];

- How afraid are you of getting sick from the COVID-19 virus? [five-point Likert scale, ranging from 1 (not afraid at all) to 5 (very afraid)].

\subsubsection{Intention to use}

Finally, participants were asked to rate their intention to use the two mobile applications: 1) a symptom app, and 2) a tracing app. The statements for the construct intention to use were based on Van Velsen et al., 2015 [12]. All three questions were accompanied by a five-point Likert scale 
medRxiv preprint doi: https://doi.org/10.1101/2020.06.02.20113423; this version posted June 2, 2020. The copyright holder for this preprint (which was not certified by peer review) is the author/funder, who has granted medRxiv a license to display the preprint in perpetuity.

All rights reserved. No reuse allowed without permission.

ranging from 1 (strongly disagree) to 5 (strongly agree). Next to these closed questions, respondents were also asked what the main reasons were to 'use' and 'not to use' the mobile applications.

\subsection{Survey distribution}

Distribution of the survey started on April 15, 2020. Participants were eligible if they were 18 years of age or older. We used a snowball sampling via posts on social media (Linkedln, Twitter and Facebook) and personal connections. Next to this, we recruited participants via a Dutch panel of older adults that indicated they were interested in participating in research on the topic of eHealth. The survey was closed on April 30, 2020. Due to the method of recruitment, a response rate could not be calculated.

\subsection{Analyses}

Data were analysed by using SPSS, version 19. Descriptive statistics were performed for all outcomes. Cronbach's alphas were calculated to assess internal consistency for attitude towards technology, perceived health, fear of COVID-19 and intention to use. Next, survey scores were interpreted for these factors as being negative (score 1 or 2), neutral (score of 3), or positive (score 4 or 5). Via a paired t-test, the difference in intention to use score between both mobile applications was tested. To identify antecedents of acceptance of 1) a symptom app, and 2) a tracing app, we conducted multiple linear regression analyses (backward model analyses). The intention to use each app was used as the dependent variable. The independent variables were those demographic characteristics and factors that (borderline) significant correlated (Pearson Correlation cut-off level $p \leq 0.10$ ) with the dependent variable. For the paired t-test and regression analyses, the level of significance was set at $p<0.05$.

\section{Results}

In total, 238 Dutch citizens completed the survey. Fifteen responders only completed the intention to use survey of a tracing app as this app was presented first and these responders stopped with the survey after these questions. Almost $60 \%$ of the responders were female and the average age was 45.6 years ( $S D \pm 17.4)$. Only five responders ( $2.1 \%$ ) did not own a smartphone and almost $75 \%$ claimed that they carried their smartphone with them for most of the day. The internal consistence of the attitude towards technology scale was good (Cronbach's Alpha $=0.85)$. Most responders (73.9\%) had a moderate attitude towards technology. Only three responders (1.3\%) claimed to be infected with COVID-19. All demographic characteristics are presented in table 1.

Table 1: Responders' demographics.

\begin{tabular}{|l|l|c|}
\hline Demographic (n=238) & & \\
\hline Gender & Male & $40.8 \%$ \\
\hline & Female & $59.2 \%$ \\
\hline Age & & $45.6($ SD \pm 17.4$)$ years \\
\hline Smartphone & Yes & $97.9 \%$ \\
\hline & No & $2.1 \%$ \\
\hline Carry smartphone with you? & Always & $74.8 \%$ \\
\hline & Sometimes & $23.1 \%$ \\
\hline & Never & $2.1 \%$ \\
\hline Education level & Student & $6.7 \%$ \\
\hline & Primary school & $0.8 \%$ \\
\hline & Secondary school & $5.9 \%$ \\
\hline & High school & $23.9 \%$ \\
\hline
\end{tabular}


medRxiv preprint doi: https://doi.org/10.1101/2020.06.02.20113423; this version posted June 2, 2020. The copyright holder for this preprint (which was not certified by peer review) is the author/funder, who has granted medRxiv a license to display the preprint in perpetuity.

All rights reserved. No reuse allowed without permission.

\begin{tabular}{|l|l|c|}
\hline & Bachelor's degree / University / PhD & $62.6 \%$ \\
\hline Work status & Unemployed and searching for work & $1.3 \%$ \\
\hline & Not able to work due to illness & $3.4 \%$ \\
\hline & Volunteer work & $0.8 \%$ \\
\hline & Part-time work & $31.5 \%$ \\
\hline & Full-time work & $34.4 \%$ \\
\hline & Retired & $18.1 \%$ \\
\hline & Student & $10.5 \%$ \\
\hline Income level & Below average wages & $31.9 \%$ \\
\hline & Average wages & $39.1 \%$ \\
\hline & Above average wages & $29 \%$ \\
\hline Living status & Living alone & $14.3 \%$ \\
\hline & Living together & $80.3 \%$ \\
\hline & Other & $5.5 \%$ \\
\hline Attitude towards technology & & $3.2($ SD \pm 0.78$)[1-5]$ \\
\hline & Low (1-2) & $1.3 \%$ \\
\hline & Moderate (3) & $73.9 \%$ \\
\hline & High (4-5) & $24.8 \%$ \\
\hline COVID-19 infection & Yes & $1.3 \%$ \\
\hline & In doubt & $18.5 \%$ \\
\hline & No & $80.3 \%$ \\
\hline
\end{tabular}

\subsection{Fear of a COVID-19 infection}

The internal consistency of the four items in this scale was acceptable to good (Cronbach's Alpha = 0.78 ). The mean score on this topic was $3.3(\mathrm{SD} \pm 0.68)$. The majority of the responder's opinion on this topic was neutral (80.7\%) and $16 \%$ of the responders were afraid for a COVID-19 infection. Only a few responders (3.4\%) were not afraid (table 2 ).

\subsection{Perceived health}

For the three items to assess the perceived health of the responders the internal consistence was acceptable (Cronbach's Alpha $=0.69)$. The mean score on this scale was $3.8(S D \pm 0.68)$. Most respondents were positive about their health (58.4\%).

\subsection{Intention to use}

The intention to use was assessed for the symptom app and the tracing app. For both scales, internal consistency was excellent; Cronbach's Alpha symptom app $=0.96$ and Cronbach's Alpha tracing app $=0.96$. For both apps, the majority's intention to use was neutral (see table 2). However, an additional paired t-test indicated that there is a significant difference in the scores on intention to use for the symptom app ( $M=3.38, S D \pm 1.07, n=223)$ and the tracing app ( $M=3.27, S D \pm 1.13, n=223)$; $t(222)=-2.598$ and $p=0.01$. Indicating that the responders were more willing to use a mobile application for COVID-19 symptom recognition and monitoring compared to a mobile application for contact tracing.

Table 2: Descriptive statistics and internal consistency of scales.

\begin{tabular}{|l|c|c|c|c|c|c|}
\hline Scale & $\begin{array}{c}\text { Number } \\
\text { of items }\end{array}$ & $\begin{array}{c}\text { Cronbach's } \\
\text { Alpha }\end{array}$ & Mean (SD) & Positive & Neutral & Negative \\
\hline Fear of COVID-19 & 4 & 0.78 & $3.3(\mathrm{SD} \pm 0.68)$ & $16 \%$ & $80.7 \%$ & $3.4 \%$ \\
\hline Perceived health & 3 & 0.69 & $3.8(\mathrm{SD} \pm 0.68)$ & $58.4 \%$ & $40.8 \%$ & $0.8 \%$ \\
\hline
\end{tabular}


medRxiv preprint doi: https://doi.org/10.1101/2020.06.02.20113423; this version posted June 2,2020 . The copyright holder for this preprint (which was not certified by peer review) is the author/funder, who has granted medRxiv a license to display the preprint in perpetuity.

All rights reserved. No reuse allowed without permission.

\begin{tabular}{|c|c|c|c|c|c|c|}
\hline \multicolumn{7}{|c|}{ Symptom app $(n=223)$} \\
\hline Intention to use & 3 & 0.96 & $\begin{array}{c}3.38 \\
(S D \pm 1.07) \\
\end{array}$ & $45.3 \%$ & $45.3 \%$ & $9.4 \%$ \\
\hline \multicolumn{7}{|c|}{ Tracing app $(n=238)$} \\
\hline Intention to use & 3 & 0.96 & $\begin{array}{c}3.27 \\
(S D \pm 1.14)\end{array}$ & $41.2 \%$ & $45.4 \%$ & $13.4 \%$ \\
\hline
\end{tabular}

\subsection{Correlations}

The intention to use a symptom app is related to income level $(r=0.132, p<0.05)$, attitude towards technology $(r=0.220, p<0.01)$ and fear of COVID-19 $(r=-0.291, p<0.01)$. The intention to use a tracing app is related to age $(r=0.135, p=0.04)$, attitude towards technology $(r=0.223, p<0.01)$ and fear of COVID-19 ( $r=-0.303, p<0.01)$. Based on these outcomes the independent variables within the linear regression analysis were: age, income level, attitude towards technology, fear of COVID-19 and perceived health. Table 3 provides an overview of the correlations between all demographics and factors, and the intention to use.

Table 3: Outcome Pearson Correlation.

\begin{tabular}{|l|c|c|}
\hline & $\begin{array}{c}\text { Intention to use } \\
\text { symptom app }(\mathrm{n}=223)\end{array}$ & $\begin{array}{c}\text { Intention to use } \\
\text { tracing app }(\mathrm{n}=238)\end{array}$ \\
\hline Gender & $\mathrm{r}=-0.056$ & $\mathrm{p}=-0.147$ \\
& $\mathrm{p}=0.41$ & $\mathrm{p}=0.23$ \\
\hline Age & $\mathrm{p}=0.126$ & $\mathrm{r}=0.135^{*}$ \\
& $\mathrm{r}=0.21$ & $\mathrm{p}=0.04$ \\
\hline Education level & $\mathrm{p}=0.76$ & $\mathrm{p}=0.018$ \\
& $\mathrm{r}=0.072$ & $\mathrm{r}=0.033$ \\
\hline Work status & $\mathrm{p}=0.28$ & $\mathrm{p}=0.62$ \\
\hline Income level & $\mathrm{r}=-0.132^{*}$ & $\mathrm{r}=0.124$ \\
& $\mathrm{p}=0.05$ & $\mathrm{p}=0.06$ \\
\hline Living status & $\mathrm{r}=0.083$ & $\mathrm{r}=0.060$ \\
& $\mathrm{p}=0.218$ & $\mathrm{p}=0.353$ \\
\hline Attitude towards & $\mathrm{r}=0.220^{*}$ & $\mathrm{r}=0.223^{*}$ \\
technology & $\mathrm{p}<0.01$ & $\mathrm{p}<0.01$ \\
\hline Fear of COVID-19 & $\mathrm{r}=-0.291^{*}$ & $\mathrm{r}=-0.303^{*}$ \\
& $\mathrm{p}<0.01$ & $\mathrm{p}<0.01$ \\
\hline Perceived health & $\mathrm{r}=-0.088$ & $\mathrm{r}=-0.119$ \\
& $\mathrm{p}=0.19$ & $\mathrm{p}=0.07$ \\
\hline
\end{tabular}

${ }^{*}$ Correlation is significant at the 0.05 level (2-tailed).

\subsubsection{Linear regression}

A multiple linear regression analysis was conducted to predict the intention to use a symptom app based on age, income level, attitude towards technology, fear of COVID-19 and perceived health. The final model included the predictors attitude towards technology, fear of COVID-19, and age. The model has an $\mathrm{R}^{2}$ of 0.141 . It contains three factors that affect the intention to use, but only two of them are significant predictors:

- $\quad$ Fear of COVID-19, $\beta=0.272, t=4.305, p<0.001$; 
medRxiv preprint doi: https://doi.org/10.1101/2020.06.02.20113423; this version posted June 2, 2020. The copyright holder for this preprint (which was not certified by peer review) is the author/funder, who has granted medRxiv a license to display the preprint in perpetuity.

All rights reserved. No reuse allowed without permission.

- $\quad$ Attitude towards technology, $\beta=0.222, t=3.532, p<0.01$;

- Age, $\beta=0.107, t=1.691$, not significant.

Another multiple linear regression analysis was conducted to predict the intention to use a tracing app based on age, income level, attitude towards technology, fear of COVID-19 and perceived health. The final model included the predictors attitude towards technology, fear of COVID-19, and age. The model has a $R^{2}$ of 0.155 . Intention to use is predicted by:

- $\quad$ Fear of COVID-19, $\beta=0.286, t=4.742, p<0.001$;

- $\quad$ Attitude towards technology, $\beta=0.230, t=3.815, p<0.001$;

- $\quad$ Age, $\beta=0.128, t=2.104, p<0.05$.

\subsection{Main reason to use the mobile applications}

An overview of all reasons the responders brought forth for using both mobile applications is presented in table 4 . The main reason (28.4\%) for responders to use the symptom app, was to control the spread of the COVID-19 virus. In addition, respondents were willing to use this mobile application to monitor own complaints (19.0\%) and to gain more insight into the spread and symptoms of the COVID-19 virus (16.4\%).

The main reason to use a tracing app was also to control the spread of the COVID-19 virus (30.6\%). Next to this, respondents were willing to use this mobile application to gain more insight into the spread and symptoms of the COVID-19 virus (23.1\%) and for one's own health (12.9\%).

Table 4: Overview of the main reasons to use the two mobile applications.

\begin{tabular}{|l|c|l|c|}
\hline \multicolumn{2}{|c|}{ Main reasons to use a symptom app (n=116) } & \multicolumn{2}{c|}{ Main reasons to use a tracing app (n=147) } \\
\hline $\begin{array}{l}\text { To control the spread of the COVID- } \\
19 \text { virus in general }\end{array}$ & $28.4 \%$ & $\begin{array}{l}\text { To control the spread of the COVID- } \\
19 \text { virus in general }\end{array}$ & $30.6 \%$ \\
\hline To monitor own complaints & $19.0 \%$ & $\begin{array}{l}\text { More insight into the spread and } \\
\text { symptoms of COVID-19 }\end{array}$ & $23.1 \%$ \\
\hline $\begin{array}{l}\text { More insight into the spread and } \\
\text { symptoms of COVID-19 }\end{array}$ & $16.4 \%$ & For one's own health & $12.9 \%$ \\
\hline $\begin{array}{l}\text { To control the spread of the COVID- } \\
19 \text { virus for oneself }\end{array}$ & $12.9 \%$ & For safety & $11.6 \%$ \\
\hline For one's own health & $10.3 \%$ & $\begin{array}{l}\text { To control the spread of the COVID- } \\
19 \text { virus for oneself }\end{array}$ & $10.2 \%$ \\
\hline For safety & $6.0 \%$ & For society & $6.1 \%$ \\
\hline For society & $4.3 \%$ & To protect the frail population & $4.1 \%$ \\
\hline To protect the frail population & $1.7 \%$ & Out of fear & $1.4 \%$ \\
\hline Out of fear & $0.9 \%$ & & \\
\hline
\end{tabular}

\subsection{Main reason not to use the mobile applications}

An overview of the reasons not to use the mobile applications is presented in table 5 . For both mobile applications, privacy was mentioned as the main reason (symptom app $=55.7 \%$ and tracing app $=64.8 \%$ ) not to use the mobile applications. Other reasons for not using the mobile applications were the expected usefulness of the application (symptom app=23.5\% and tracing app $=13.4 \%$ ) and a fear of becoming over aware of the situation and its potential consequences, leading to unnecessary stress (symptom app $=7.8 \%$ and tracing app $=11.3 \%$ ).

Table 5: Overview of the main reasons not to use the two mobile applications. 
medRxiv preprint doi: https://doi.org/10.1101/2020.06.02.20113423; this version posted June 2, 2020. The copyright holder for this preprint (which was not certified by peer review) is the author/funder, who has granted medRxiv a license to display the preprint in perpetuity.

All rights reserved. No reuse allowed without permission.

\begin{tabular}{|l|c|l|c|}
\hline \multicolumn{2}{|l|}{ Main reasons to use a symptom app (n=113) } & \multicolumn{2}{l|}{ Main reasons not to use a tracing app (n=142) } \\
\hline $\begin{array}{l}\text { Privacy / not willing to share } \\
\text { information with government }\end{array}$ & $55.7 \%$ & $\begin{array}{l}\text { Privacy / not willing to share } \\
\text { information with government }\end{array}$ & $64.8 \%$ \\
\hline Doubting usefulness & $23.5 \%$ & Doubting usefulness & $13.4 \%$ \\
\hline Over awareness / stress & $7.8 \%$ & Over awareness / stress & $11.3 \%$ \\
\hline Doubting ease of use & $4.3 \%$ & No (compatible) phone & $4.2 \%$ \\
\hline Doubting security & $4.3 \%$ & Doubting security & $2.1 \%$ \\
\hline No (compatible) phone & $1.7 \%$ & Doubting ease of use & $2.1 \%$ \\
\hline $\begin{array}{l}\text { The fear the use of the app will be } \\
\text { forces by government }\end{array}$ & $0.9 \%$ & $\begin{array}{l}\text { The fear the use of the app will be } \\
\text { forces by government }\end{array}$ & $2.1 \%$ \\
\hline
\end{tabular}

\section{Discussion}

The aim of this paper was to identify antecedents of acceptance of 1 ) a mobile application for COVID-19 symptom recognition and monitoring, and 2) a mobile application for contact tracing among Dutch citizens by means of an online survey. A large group of the Dutch citizens $(45.3 \%)$ is willing to use a mobile application for COVID-19 symptom recognition and monitoring. The main reasons to use this mobile application are: 1 . To control the spread of the COVID-19; 2. To monitor their own complaints; and 3. To gain more insight into the spread and symptoms of the COVID-19 virus. For the case of a mobile application for COVID-19 contact tracing, $41.2 \%$ of the Dutch adults appears to be willing to use this mobile application. The main reasons for use are: 1 . To control the spread of the COVID-19 virus; 2 . To gain more insight into the spread and symptoms of the COVID-19 virus; and 3. For their own health. Privacy, doubting the usefulness of the mobile application and a fear of becoming over aware of the situation and its potential consequences, leading to unnecessary stress are the main reasons not to use the mobile applications. For both mobile applications age, attitude towards technology and fear of COVID-19 are antecedents of acceptance.

It is difficult to relate our findings to the existing literature, as technology acceptance studies have not focused on mobile applications to be used during a pandemic, and insights on factors that determine the acceptance of COVID-19 related mobile applications are lacking [8]. In general, age and attitude towards technology are widely-acknowledged antecedents of acceptance. For age there is evidence that older age is associated with lower level of acceptance of mobile applications [13]. Previous results also indicated that attitude towards technology is an important antecedent of acceptance of mobile applications $[13,14]$. The degree to which an individual is willing to try out any new mobile application is related to the intention to use [13].

Our results show that fear of COVID-19 is the most important COVID-19-related factor that predicts acceptance of mobile applications to deal with the COVID-19 pandemic. Since it is difficult to translate this fear into technology design, this finding needs to be seen in a bigger picture. Public health campaigns during the COVID-19 epidemic will need to educate citizens about the dangers of COVID-19 (personally and for society as a whole), and should then offer downloading COVID-19 mobile applications as a personal strategy to deal with this fear. Next, the positive attitude towards technology that precedes a decision to download a COVID-19 app should be taken into consideration when using these innovations. The end-user population might be skewed towards those with interest in technology (traditionally these are younger, highly-educated men [15]) which can create a use divide, and thus, a health divide in society. Measures should be installed to support those groups in society that are not, by nature, technically interested, like promotional stalls in the community and diverse channels of user support. 
medRxiv preprint doi: https://doi.org/10.1101/2020.06.02.20113423; this version posted June 2, 2020. The copyright holder for this preprint (which was not certified by peer review) is the author/funder, who has granted medRxiv a license to display the preprint in perpetuity.

All rights reserved. No reuse allowed without permission.

The following four limitations should be taken into account for this study. First, the selection bias of our sample. Given the results the education level of our sample is higher compared to the general population. In addition, most respondents had a moderate attitude towards technology. This could be explained by our way to distribute the survey by snowball sampling. Second, for our analysis the power of our sample was sufficient. However, a larger sample would improve the generalizability of our outcomes as mainly Dutch citizens from the eastern part of the Netherlands ( $87 \%$ of our sample) completed our survey. Third, in our survey the two mobile applications are introduced by means of a short description of their general aim. It is unclear if this description was sufficient for the responders to understand to purpose of both mobile applications. Fourth, the explained variance of both our models is relatively low. Normally, in studies such as these, this number is boosted by including the predictors ease of use and perceived usefulness. However, since including these factors leads to little practical results (concluding that the applications should be easy to use is a given and does not inform design), the identification COVID-19-related factors is an important extension of existing technology acceptance models.

\section{Conclusion}

This study is the first to determine the factors related to the acceptance of COVID-19 apps. Age, attitude towards technology and fear of COVID-19 are important predictors of the acceptance of COVID-19 mobile applications for symptom recognition and monitoring and for contact tracing. These predictors should be taken into account during the development and implementation of these mobile applications to secure acceptance.

\section{Authors' contributions}

The survey was developed by SJK, MH and LVV. Statistical analyses were performed by SJK and LVV. All authors were involved in the distribution of the survey and participated in drafting the article and revising it critically for important intellectual content.

\section{Acknowledgments}

Not applicable

\section{Summary table}

\begin{tabular}{|c|c|}
\hline What was already known on the topic: & What this study added to our knowledge: \\
\hline $\begin{array}{l}\text { - eHealth applications have been } \\
\text { recognized as a valuable tool to reduce } \\
\text { COVID-19's effective reproduction } \\
\text { number by means of timely } \\
\text { intervention } \\
\text { - The factors that determine acceptance } \\
\text { of COVID-19 apps are unknown } \\
\text { eHealth could be a solution to rapidly } \\
\text { cope with health demands during a } \\
\text { pandemic as an addition to the health } \\
\text { care infrastructure }\end{array}$ & $\begin{array}{l}\text { - } 41-45 \% \text { of the Dutch adults are willing to } \\
\text { use mHealth to prevent the spread of } \\
\text { COVID-19 } \\
\text { - Age, attitude towards technology and fear } \\
\text { of COVID-19 predict the intention to use } \\
\text { mHealth to prevent the spread of COVID- } \\
19 \\
\text { - The main reasons to use this application } \\
\text { are to control the spread of the COVID-19 } \\
\text { virus for the general purpose, to monitor } \\
\text { their own complaints and to gain more } \\
\text { insight into the spread and symptoms of } \\
\text { the COVID-19 virus } \\
\text { Privacy, doubting the usefulness of the } \\
\text { mHealth application and fear of over } \\
\text { awareness leading to unnecessary stress }\end{array}$ \\
\hline
\end{tabular}


medRxiv preprint doi: https://doi.org/10.1101/2020.06.02.20113423; this version posted June 2, 2020. The copyright holder for this preprint (which was not certified by peer review) is the author/funder, who has granted medRxiv a license to display the preprint in perpetuity.

\begin{tabular}{|l|l|}
\hline & $\begin{array}{l}\text { are the main reasons not to use mHealth } \\
\text { to prevent the spread of COVID-19 }\end{array}$ \\
\hline
\end{tabular}

\section{References}

1. Fang, L., G. Karakiulakis, and M. Roth, Are patients with hypertension and diabetes mellitus at increased risk for COVID-19 infection? The Lancet Respiratory Medicine, 2020. 8(4): p. e21.

2. Huang, C., et al., Clinical features of patients infected with 2019 novel coronavirus in Wuhan, China. The Lancet, 2020. 395(10223): p. 497-506.

3. Roux, J., C. Massonnaud, and P. Crépey, COVID-19: One-month impact of the French lockdown on the epidemic burden. medRxiv, 2020: p. 2020.04.22.20075705.

4. Di Domenico, L., et al., Expected impact of lockdown in île-de-France and possible exit strategies. medRxiv, 2020: p. 2020.04.13.20063933.

5. Krausz, M., et al., Emergency Response to COVID-19 in Canada: Platform Development and Implementation for eHealth in Crisis Management. JMIR Public Health Surveill, 2020. 6(2): p. e18995.

6. Ferretti, L., et al., Quantifying SARS-CoV-2 transmission suggests epidemic control with digital contact tracing. Science, 2020. 368(6491): p. eabb6936.

7. Hinch, R., et al., Effective Configurations of a Digital Contact Tracing App: A report to NHSX. en. In:(Apr. 2020). Available here. url: https://github. com/BDI-pathogens/covid19_instant_tracing/blob/master/Report, 2020.

8. Thorneloe, R., et al., SCOPING REVIEW OF MOBILE PHONE APP UPTAKE AND ENGAGEMENT TO INFORM DIGITAL CONTACT TRACING TOOLS FOR COVID-19. 2020.

9. Anderson, K., O. Burford, and L. Emmerton, Mobile health apps to facilitate self-care: a qualitative study of user experiences. PLoS One, 2016. 11(5): p. e0156164.

10. Agarwal, R. and J. Prasad, A Conceptual and Operational Definition of Personal Innovativeness in the Domain of Information Technology. Information Systems Research, 1998. 9(2): p. 204-215.

11. van Velsen, L., et al., Public knowledge and preventive behavior during a large-scale Salmonella outbreak: results from an online survey in the Netherlands. BMC Public Health, 2014. 14(1): p. 100.

12. van Velsen, L., et al., Personalization has a Price, Controllability is the Currency: Predictors for the Intention to use Personalized eGovernment Websites. Journal of Organizational Computing and Electronic Commerce, 2015. 25(1): p. 76-97.

13. Rai, A., et al., Understanding Determinants of Consumer Mobile Health Usage Intentions, Assimilation, and Channel Preferences. J Med Internet Res, 2013. 15(8): p. e149.

14. Hussein, Z., S.W. Oon, and A. Fikry, Consumer Attitude: Does It Influencing the Intention to Use mHealth? Procedia Computer Science, 2017. 105: p. 340-344.

15. Rojas-Méndez José, I., A. Parasuraman, and N. Papadopoulos, Demographics, attitudes, and technology readiness: A cross-cultural analysis and model validation. Marketing Intelligence \& Planning, 2017. 35(1): p. 18-39. 
medRxiv preprint doi: https://doi.org/10.1101/2020.06.02.20113423; this version posted June 2, 2020. The copyright holder for this preprint (which was not certified by peer review) is the author/funder, who has granted medRxiv a license to display the preprint in perpetuity.

All rights reserved. No reuse allowed without permission.

\section{Appendix 1}

Table 6: Survey questions and answer options in Dutch and English. ( $D=$ demographic questions $/ C=$ fear of COVID-19 questions / $\mathrm{H}=$ perceived health questions / TAM-BI= behavioural intention)

\begin{tabular}{|c|c|c|c|c|c|}
\hline & & Dutch & & English & \\
\hline D & 1 & Wat is uw geslacht? & $\begin{array}{l}\text { o Man } \\
\text { o Vrouw }\end{array}$ & $\begin{array}{l}\text { What is your } \\
\text { gender? }\end{array}$ & $\begin{array}{l}\text { o Men } \\
\text { o Women }\end{array}$ \\
\hline $\mathrm{D}$ & 2 & Wat is uw leeftijd? & & What is your age? & \\
\hline $\mathrm{D}$ & 3 & \multicolumn{2}{|c|}{ Wat zijn de 4 cijfers van uw postcode? } & \multicolumn{2}{|c|}{ What are the 4 digits of your zip code? } \\
\hline D & 4 & $\begin{array}{l}\text { Heeft u een } \\
\text { smartphone? }\end{array}$ & $\begin{array}{l}\text { o Ja } \\
\text { o Nee }\end{array}$ & $\begin{array}{l}\text { Do you have a } \\
\text { smartphone? }\end{array}$ & $\begin{array}{l}\text { o Yes } \\
\text { o No }\end{array}$ \\
\hline D & 5 & $\begin{array}{l}\text { Draagt u uw } \\
\text { smartphone de hele } \\
\text { dag bij u? }\end{array}$ & $\begin{array}{l}\text { o Nooit } \\
\text { o Soms } \\
\text { o Altijd }\end{array}$ & $\begin{array}{l}\text { Do you carry your } \\
\text { smartphone with } \\
\text { you all day? }\end{array}$ & $\begin{array}{l}\text { o Never } \\
\text { o Sometimes } \\
\text { o Always }\end{array}$ \\
\hline D & 6 & $\begin{array}{l}\text { Wat is de hoogste } \\
\text { opleiding die u heeft } \\
\text { afgerond? }\end{array}$ & $\begin{array}{l}\text { o Basisschool } \\
\text { o Lbo, mavo, vmbo } \\
\text { o Mbo, havo, vwo } \\
\text { o Hbo, wo } \\
\text { o lk studeer nog }\end{array}$ & $\begin{array}{l}\text { What is the highest } \\
\text { level of education } \\
\text { you have } \\
\text { completed? }\end{array}$ & $\begin{array}{l}\text { o Primary school } \\
\text { o vocation } \\
\text { education } \\
\text { o vocational } \\
\text { education } \\
\text { o higher education } \\
\text { o I am still studying }\end{array}$ \\
\hline $\mathrm{D}$ & 7 & $\begin{array}{l}\text { Welke van de } \\
\text { volgende categorieën } \\
\text { beschrijft uw } \\
\text { werkstatus het best? }\end{array}$ & $\begin{array}{l}\text { o Werkloos, op zoek } \\
\text { naar werk } \\
\text { o Werkloos, niet op } \\
\text { zoek naar werk } \\
\text { o Part-time werkzaam } \\
\text { o Full-time werkzaam } \\
\text { o Gepensioneerd } \\
\text { o Door ziekte niet de } \\
\text { mogelijkheid om te } \\
\text { werken } \\
\text { o Student } \\
\text { o Vrijwilligerswerk }\end{array}$ & $\begin{array}{l}\text { Which of the } \\
\text { following categories } \\
\text { best describes your } \\
\text { work status? }\end{array}$ & $\begin{array}{l}\text { o Unemployed, } \\
\text { looking for work } \\
\text { o Unemployed, not } \\
\text { looking for work } \\
\text { o Working part-time } \\
\text { o Working full-time } \\
\text { o Retired } \\
\text { o Not able to work } \\
\text { due to illness } \\
\text { o Student } \\
\text { o Volunteering }\end{array}$ \\
\hline $\mathrm{D}$ & 8 & $\begin{array}{l}\text { Wat is uw gemiddelde } \\
\text { inkomen? (Modaal } \\
\text { inkomen = €36.000 } \\
\text { bruto per jaar) }\end{array}$ & $\begin{array}{l}\text { o Beneden modaal } \\
\text { o Rond modaal } \\
\text { o Boven modaal }\end{array}$ & $\begin{array}{l}\text { What is your } \\
\text { average income? } \\
\text { (Average income = } € \\
36,000 \text { gross per } \\
\text { year) }\end{array}$ & $\begin{array}{l}\text { o Below average } \\
\text { o Around average } \\
\text { o Above average }\end{array}$ \\
\hline D & 9 & $\begin{array}{l}\text { Bent } u \text { alleen of } \\
\text { woont u samen? }\end{array}$ & $\begin{array}{l}\text { o Alleenstaand } \\
\text { o Samenwonend } \\
\text { o Anders }\end{array}$ & $\begin{array}{l}\text { Are you single or do } \\
\text { you live together? }\end{array}$ & $\begin{array}{l}\text { o Single } \\
\text { o Living together } \\
\text { o Otherwise }\end{array}$ \\
\hline \multirow[t]{3}{*}{$\mathrm{D}$} & \multirow[t]{3}{*}{10} & \multicolumn{2}{|c|}{$\begin{array}{l}\text { Hoe denkt u over nieuwe technologieën in het } \\
\text { algemeen? Vink voor elke stelling het antwoord } \\
\text { aan dat het beste bij u past. }\end{array}$} & \multicolumn{2}{|c|}{$\begin{array}{l}\text { How do you feel about new technologies in } \\
\text { general? For each statement, tick the } \\
\text { answer that suits you best. }\end{array}$} \\
\hline & & $\begin{array}{l}\text { a. Als ik hoor over een } \\
\text { nieuwe technologie, } \\
\text { kijk ik ernaar uit om } \\
\text { dat uit te proberen }\end{array}$ & $\begin{array}{l}\text { o Zeer mee oneens } \\
\text { o Mee oneens } \\
\text { o Neutraal } \\
\text { o Mee eens } \\
\text { o Zeer mee eens }\end{array}$ & $\begin{array}{l}\text { a. When I hear } \\
\text { about a new } \\
\text { technology, I look } \\
\text { forward to trying it } \\
\text { out }\end{array}$ & $\begin{array}{l}\text { o Strongly disagree } \\
\text { o I disagree } \\
\text { o Neutral } \\
\text { o Agree } \\
\text { o Strongly agree }\end{array}$ \\
\hline & & $\begin{array}{l}\text { b. Vergeleken met de } \\
\text { mensen in mijn } \\
\text { omgeving ben ik } \\
\text { meestal een van de } \\
\text { eersten die nieuwe }\end{array}$ & $\begin{array}{l}\text { o Zeer mee oneens } \\
\text { o Mee oneens } \\
\text { o Neutraal } \\
\text { o Mee eens } \\
\text { o Zeer mee eens }\end{array}$ & $\begin{array}{l}\text { b. Compared to the } \\
\text { people around me, } \\
\text { I'm usually one of } \\
\text { the first to try out } \\
\text { new technologies }\end{array}$ & $\begin{array}{l}\text { o Strongly disagree } \\
\text { o I disagree } \\
\text { o Neutral } \\
\text { o Agree } \\
\text { o Strongly agree }\end{array}$ \\
\hline
\end{tabular}


medRxiv preprint doi: https://doi.org/10.1101/2020.06.02.20113423; this version posted June 2, 2020. The copyright holder for this preprint (which was not certified by peer review) is the author/funder, who has granted medRxiv a license to display the preprint in perpetuity.

All rights reserved. No reuse allowed without permission.

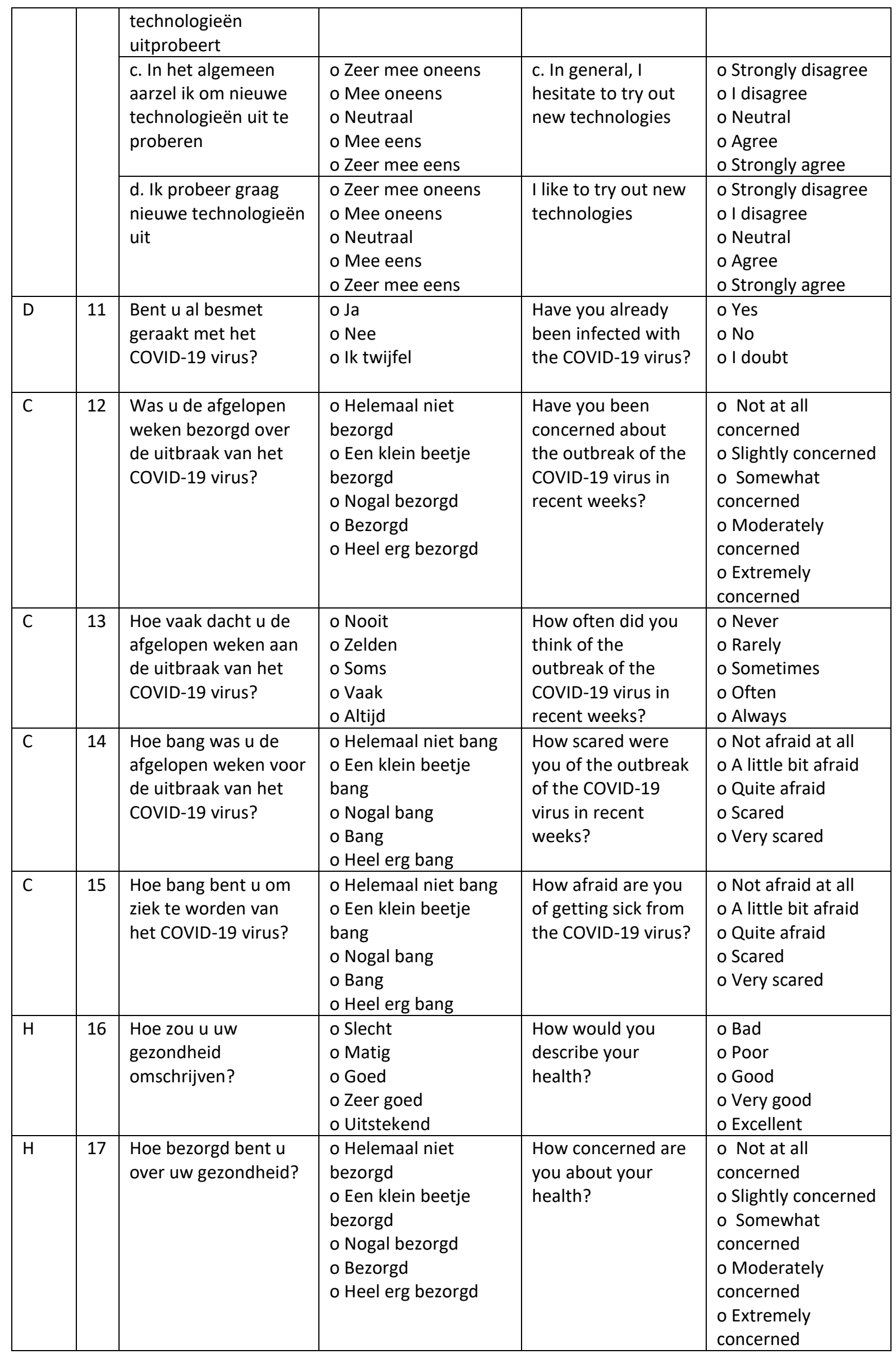


medRxiv preprint doi: https://doi.org/10.1101/2020.06.02.20113423; this version posted June 2, 2020. The copyright holder for this preprint (which was not certified by peer review) is the author/funder, who has granted medRxiv a license to display the preprint in perpetuity.

All rights reserved. No reuse allowed without permission.

\begin{tabular}{|c|c|c|c|c|c|}
\hline $\mathrm{H}$ & 18 & $\begin{array}{l}\text { Ik ben vaker ziek dan } \\
\text { andere mensen van } \\
\text { dezelfde leeftijd en } \\
\text { hetzelfde geslacht. }\end{array}$ & $\begin{array}{l}\text { o Zeer mee oneens } \\
\text { o Mee oneens } \\
\text { o Neutraal } \\
\text { o Mee eens } \\
\text { o Zeer mee eens }\end{array}$ & $\begin{array}{l}\text { I am sick more often } \\
\text { than other people } \\
\text { of the same age and } \\
\text { gender. }\end{array}$ & $\begin{array}{l}\text { o Strongly disagree } \\
\text { o I disagree } \\
\text { o Neutral } \\
\text { o Agree } \\
\text { o Strongly agree }\end{array}$ \\
\hline TAM & 19 & \multicolumn{2}{|c|}{$\begin{array}{l}\text { Hieronder krijgt u stellingen die gaan over uw } \\
\text { verwachting over de app waarmee in kaart } \\
\text { wordt gebracht met wie een besmet persoon in } \\
\text { contact is geweest. Vink voor elke stelling het } \\
\text { antwoord aan wat het best aan uw verwachting } \\
\text { voldoet. }\end{array}$} & \multicolumn{2}{|c|}{$\begin{array}{l}\text { Below you will find statements about your } \\
\text { expectation about the app to determine if } \\
\text { an infected person has been contacted with } \\
\text { others. For each statement, tick the answer } \\
\text { that best meets your expectations. }\end{array}$} \\
\hline \multirow{3}{*}{\multicolumn{2}{|c|}{ TAM-BI }} & $\begin{array}{l}\text { a. Ik ben van plan } \\
\text { deze App te gebruiken } \\
\text { zo vaak als nodig is. }\end{array}$ & $\begin{array}{l}\text { o Zeer mee oneens } \\
\text { o Mee oneens } \\
\text { o Neutraal } \\
\text { o Mee eens } \\
\text { o Zeer mee eens }\end{array}$ & $\begin{array}{l}\text { a. I plan to use this } \\
\text { App as often as } \\
\text { necessary. }\end{array}$ & $\begin{array}{l}\text { o Strongly disagree } \\
\text { o I disagree } \\
\text { o Neutral } \\
\text { o Agree } \\
\text { o Strongly agree }\end{array}$ \\
\hline & & $\begin{array}{l}\text { b. Als deze App } \\
\text { beschikbaar zou zijn } \\
\text { voor mij, zou ik deze } \\
\text { absoluut gebruiken. }\end{array}$ & $\begin{array}{l}\text { o Zeer mee oneens } \\
\text { o Mee oneens } \\
\text { o Neutraal } \\
\text { o Mee eens } \\
\text { o Zeer mee eens }\end{array}$ & $\begin{array}{l}\text { b. If this App were } \\
\text { available to me, I } \\
\text { would absolutely } \\
\text { use it. }\end{array}$ & $\begin{array}{l}\text { o Strongly disagree } \\
\text { o I disagree } \\
\text { o Neutral } \\
\text { o Agree } \\
\text { o Strongly agree }\end{array}$ \\
\hline & & $\begin{array}{l}\text { c. Ik hoop dat deze } \\
\text { App beschikbaar komt } \\
\text { voor mij. }\end{array}$ & $\begin{array}{l}\text { o Zeer mee oneens } \\
\text { o Mee oneens } \\
\text { o Neutraal } \\
\text { o Mee eens } \\
\text { o Zeer mee eens }\end{array}$ & $\begin{array}{l}\text { c. I hope this App } \\
\text { becomes available } \\
\text { to me. }\end{array}$ & $\begin{array}{l}\text { o Strongly disagree } \\
\text { o I disagree } \\
\text { o Neutral } \\
\text { o Agree } \\
\text { o Strongly agree }\end{array}$ \\
\hline & 20 & \multicolumn{2}{|c|}{$\begin{array}{l}\text { Wat is voor } u \text { de belangrijkste reden om gebruik } \\
\text { te maken van deze App? }\end{array}$} & \multicolumn{2}{|c|}{$\begin{array}{l}\text { What is the main reason for you to use this } \\
\text { App? }\end{array}$} \\
\hline & 21 & \multicolumn{2}{|c|}{$\begin{array}{l}\text { Wat is voor } u \text { de belangrijkste reden om geen } \\
\text { gebruik te maken van deze App? }\end{array}$} & \multicolumn{2}{|c|}{$\begin{array}{l}\text { What is the main reason for you not to use } \\
\text { this App? }\end{array}$} \\
\hline TAM & 22 & \multicolumn{2}{|c|}{$\begin{array}{l}\text { Hieronder krijgt u stellingen die gaan over uw } \\
\text { verwachting over de app om symptomen van u, } \\
\text { als eventuele corona patiënt, te volgen. Vink } \\
\text { voor elke stelling het antwoord aan wat het } \\
\text { best aan uw verwachting voldoet. }\end{array}$} & \multicolumn{2}{|c|}{$\begin{array}{l}\text { Below you will find statements about your } \\
\text { expectation about the app to track your } \\
\text { symptoms as corona patient. For each } \\
\text { statement, tick the answer that best meets } \\
\text { your expectations. }\end{array}$} \\
\hline \multirow{3}{*}{\multicolumn{2}{|c|}{ TAM-BI }} & $\begin{array}{l}\text { a. Ik ben van plan } \\
\text { deze App te gebruiken } \\
\text { zo vaak als nodig is. }\end{array}$ & $\begin{array}{l}\text { o Zeer mee oneens } \\
\text { o Mee oneens } \\
\text { o Neutraal } \\
\text { o Mee eens } \\
\text { o Zeer mee eens }\end{array}$ & $\begin{array}{l}\text { a. I plan to use this } \\
\text { App as often as } \\
\text { necessary. }\end{array}$ & $\begin{array}{l}\text { o Strongly disagree } \\
\text { o I disagree } \\
\text { o Neutral } \\
\text { o Agree } \\
\text { o Strongly agree }\end{array}$ \\
\hline & & $\begin{array}{l}\text { b. Als deze App } \\
\text { beschikbaar zou zijn } \\
\text { voor mij, zou ik deze } \\
\text { absoluut gebruiken. }\end{array}$ & $\begin{array}{l}\text { o Zeer mee oneens } \\
\text { o Mee oneens } \\
\text { o Neutraal } \\
\text { o Mee eens } \\
\text { o Zeer mee eens }\end{array}$ & $\begin{array}{l}\text { b. If this App were } \\
\text { available to me, I } \\
\text { would absolutely } \\
\text { use it. }\end{array}$ & $\begin{array}{l}\text { o Strongly disagree } \\
\text { o I disagree } \\
\text { o Neutral } \\
\text { o Agree } \\
\text { o Strongly agree }\end{array}$ \\
\hline & & $\begin{array}{l}\text { c. Ik hoop dat deze } \\
\text { App beschikbaar komt } \\
\text { voor mij. }\end{array}$ & $\begin{array}{l}\text { o Zeer mee oneens } \\
\text { o Mee oneens } \\
\text { o Neutraal } \\
\text { o Mee eens } \\
\text { o Zeer mee eens }\end{array}$ & $\begin{array}{l}\text { c. I hope this App } \\
\text { becomes available } \\
\text { to me. }\end{array}$ & $\begin{array}{l}\text { o Strongly disagree } \\
\text { o I disagree } \\
\text { o Neutral } \\
\text { o Agree } \\
\text { o Strongly agree }\end{array}$ \\
\hline & 23 & \multicolumn{2}{|c|}{$\begin{array}{l}\text { Wat is voor } u \text { de belangrijkste reden om gebruik } \\
\text { te maken van deze App? }\end{array}$} & \multicolumn{2}{|c|}{$\begin{array}{l}\text { What is the main reason for you to use this } \\
\text { App? }\end{array}$} \\
\hline & 24 & \multicolumn{2}{|c|}{$\begin{array}{l}\text { Wat is voor u de belangrijkste reden om geen } \\
\text { gebruik te maken van deze App? }\end{array}$} & \multicolumn{2}{|c|}{$\begin{array}{l}\text { What is the main reason for you not to use } \\
\text { this App? }\end{array}$} \\
\hline
\end{tabular}

